\title{
Body Image Evaluation of the Obese Population in a Surgical weight Reduction Context: Systematic Review
}

\author{
Thiago Gomes de Castro ${ }^{1}$ \\ Marcelle Matiazo Pinhatti \\ Universidade Federal do Rio Grande do Sul, Porto Alegre, RS, Brazil \\ Rodrigo Machado Rodrigues \\ Pontifícia Universidade Católica do Rio Grande do Sul, Porto Alegre, RS, Brazil
}

\begin{abstract}
Body image is broadly defined as the set of perceptions, thoughts and feelings of an individual about his own body. Changes in body image in severe obesity condition are consistently reported in the medical and psychological literature. The aim of this research was to investigate the set of instrumental assessment applied in studies of body image in obese within the context of surgical intervention for weight loss. We conducted a systematic review in five databases from January 2009 to December 2014. Articles in English and Portuguese were included for analysis. The search with the descriptors returned 462 records of which 15 met the inclusion criteria. Nine instruments that measure body image have been identified. There is a significant trend towards the use of self-report scales on perceived satisfaction of body image. Although the literature describes perceptual changes in body image in obese population, its evaluation prioritizes the level of subjective satisfaction with body image.
\end{abstract}

Keywords: Obesity, body image, surgery, systematic review.

\section{Avaliação de Imagem Corporal em Obesos no Contexto Cirúrgico de Redução de Peso: Revisão Sistemática}

\section{Resumo}

A imagem corporal é amplamente definida como o conjunto de percepções, pensamentos e sentimentos de um indivíduo sobre o seu próprio corpo. A alteração da imagem corporal em quadros de obesidade severa é relatada consistentemente na literatura médica e psicológica. O objetivo da presente pesquisa foi investigar o instrumental de avaliação de imagem corporal utilizado em estudos com obesos no contexto de intervenção cirúrgica de redução de peso. Realizou-se uma revisão sistemática em cinco bases de dados no período de janeiro de 2009 a dezembro de 2014. Artigos em língua inglesa e portuguesa foram incluídos para análise. A busca com os descritores retornou 462 registros dos quais 15 cumpriram os critérios de inclusão. Foram identificados nove instrumentos que mensuram imagem corporal. Destacou-se a prevalência de instrumentos de autorrelato sobre a satisfação com o próprio corpo. Embora a

Mailing address: Rua Ferreira Viana, $n^{\circ}$ 508, Apto. 302, Bairro Petrópolis, Porto Alegre, RS, Brazil, 90670100. Fone: (51) 3276-5257. E-mail: thiago.cast@gmail.com

Support National Counsel of Technological and Scientific Development (CNPq) - Bolsa de Iniciação Científica Programa Institucional de Bolsas de Iniciação Científica (PIBIC; $3^{\circ}$ autor). 
literatura descreva a alteração perceptiva da imagem corporal em obesos, a avaliação prioriza o nível de satisfação subjetiva com o próprio corpo.

Palavras-chave: Obesidade, imagem corporal, cirurgia, revisão sistemática.

\section{Evaluación de la Imagen Corporal en Obesos en el Contexto Quirúrgico de Reducción de Peso: Revisión Sistemática}

\section{Resumen}

La imagen corporal es ampliamente definida como el conjunto de percepciones, pensamientos y sentimientos de un individuo sobre su propio cuerpo. El cambio en la imagen corporal en el marco de la obesidad severa se informa constantemente en la literatura médica y psicológica. El objetivo de la investigación fue investigar el uso de instrumentos de imagen corporal en estúdios en el contexto de la cirugía de reducción de peso en los obesos. Se realizó una revisión sistemática en cinco bases de datos a partir de enero de 2009 a diciembre de 2014. Se incluyeron artículos en Inglés y Portugués para el análisis. La búsqueda con los descriptores devuelto 462 artículos de los cuales 15 cumplieron los criterios de inclusión. Se han identificado nueve instrumentos que miden la imagen corporal. Se destaca el predominio de instrumentos de auto-informe de satisfacción con sus propios cuerpos. Aunque la literatura describe el cambio de percepción de la imagen corporal en los obesos, la evaluación prioriza el nivel de satisfacción subjetiva con la imagen corporal.

Palabras clave: Obesidad, imagen corporal, cirugía, revisión sistemática.

Obesity is defined by the World Health Organization (WHO) as a condition in which excess body fat accumulation reaches an extent that may adversely affect health (WHO, 1997). Studies indicate that the etiology of obesity is multifactorial and that the main causes are related to difficulty in losing weight due to genetic factors and unhealthy lifestyle habits (Dhurandhar \& Keith, 2014; Skelton, Irby, Grzywacz, \& Miller, 2011). Other studies warn of the clinical consequences of the phenomenon, such as the strong association with type 2 diabetes mellitus, with deficits in the respiratory system and cardiovascular system, as well as a higher incidence of cancer in this population (Guh et al., 2009). Studies also indicate a relationship between obesity and adverse psychological consequences (Carr \& Jaffe, 2012; Finer, 2011). The prevalence of excess weight and obesity has increased significantly among children (Skelton, Cook, Auinger, Klein, \& Barlow, 2009), adults (Conde \& Borges, 2011) and older adults (Salihu, Bonnema, \& Alio, 2009), both in developed countries and developing countries (Popkin, 2007). It is estimated that by 2025 obesity will affect $40 \%$ of the population in the USA, $30 \%$ in England and 20\% in Brazil (Hu, 2008).

The treatment of obesity is conditional on the severity of fat concentration in the body and comorbidities associated with the condition. The most used obesity evaluation method in the West is the calculation of the body mass index (BMI), a measure used by the WHO to differentiate between grade I $(B M I \geq 30$ and $\leq 35$ ), grade II (BMI $\geq 35$ and $\leq 40$ ) and grade III obesity (BMI $>40$ ). In the stratum of grade I obesity, the traditional management for weight reduction consists of diets, nutritional reeducation and encouraging a routine of physical activities. However, more recent evidence has indicated that in situations of grade I obesity associated with comorbidities, such as type 2 diabetes, surgical interventions are more effective in managing the weight and general health of the patient (Gianos et al., 2012). From grade II obesity, considered severe, surgical treatment is the consensus in the literature as the gold standard of intervention, leading to greater weight loss and maintenance of the reduction over the long-term (Maggard et al., 2005). Non-surgical treatment modalities 
are generally ineffective in reducing weight in people with grade II and III obesity (Buchwald et al., 2004). The mean weight reduction within the two years after surgery in severely obese people is $21.6 \%$, while for non-surgical treatments this rate is only $5.5 \%$, with high rates of weight regained (Picot et al., 2009). Weight reduction surgery, in its different modalities, is considered the most effective measure to avoid the high risk to life associated with untreated severe obesity (Bruce \& Mitchell, 2014).

Obesity can lead to severe psychological consequences (Friedman \& Brownell, 1995). However, although most surgery programs for obesity recognize the importance of a psychological assessment before and after the surgery, the scope and purpose of these evaluations are highly variable. Fabricatore, Crerand, Wadden, Sarwer, and Krasucki (2006) showed that the concordance between health professionals, in the area of obesity surgery, lies in the contraindication for patients with severe psychiatric disorders. In fact, individuals with two or more psychiatric disorder diagnoses tend to lose significantly less weight after weight reduction surgery (Kinzl et al., 2006).

Regardless of psychiatric disorders, cognitive and psychosocial processes alone have been identified as potential predictors of quality of life and adaptation after bariatric surgery (Pull, 2010). Thus, in addition to the clinical diagnosis of psychiatric disorders, the investigation of reliable psychological correlates of obesity should be encouraged. Wimmelmann, Dela and Mortensen (2014) investigated psychological predictors of surgical success and failure in weight loss and found that factors such as psychiatric symptoms, self-esteem and body image in the pre-operative period were the most important for mental health after the surgery.

In this set of variables, body image emerged as a predictor of health habits related to the quality of life even two years after the weight reduction surgery (van Hout, Hagendoren, Verschure, \& van Heck, 2009). In addition, a negative body image prior to surgery is associated with less weight loss in the postoperative period, suggesting possible benefits for additional support interventions after the surgery (Ortega, Fernandez-Canet, AlvarezValdeita, Cassinello, \& Baguena-Puigcerver, 2012). However, the concept of body image is one of the most controversial in the protocols of psychological assessment for obese people.

Body image has been broadly defined as the set of perceptions, thoughts and feelings of an individual regarding his/her own body (Cash $\&$ Pruzinsky, 2002). The contributions to the concept include the investigation of subjective satisfaction with one's own body (Holsen, Carlson, \& Skogbrott, 2012), the cognitive representation of one's body (Altabe \& Thompson, 1996) and the perceptual estimation of actual and desired body size (Liechty \& Lee, 2015). This variability in the definitions has led to the construction of different assessment instruments, which is reflected in the investigation of various aspects of body image (Thompson, 2004). Accordingly, the results of different studies are difficult to compare, which prevents the construction of a robust body of evidence regarding the variable.

In the 1990s, Friedman and Brownell (1995) had already highlighted the diversification of evaluations, which they called first generation of psychological correlates of obesity. The evaluations were divided between body image depreciation and body image distortion. More recently, Pull and Aguayo (2011) reviewed the literature regarding body image instruments in obese people, covering the period 2007-2010. The researchers found a large number of instruments that did not present indices of consistency or statistical validity. In general, the instruments of the area were divided into: (a) body image evaluation via a question about satisfaction with the person's own weight, (b) self-report questionnaires about perception and satisfaction with the body image, and (c) scales of static figures or silhouettes of body image.

Considering the different definitions and instruments for body image in the literature, the aim of this study was to systematically review the empirical articles, published between 2009 and 2014, which have evaluated body image in obese patients in a context of surgical 
intervention for weight reduction. Regarding the surgical context, it was decided to include works that incorporated body image evaluation in the pre-operative or post-operative stages or both.

\section{Method}

A systematic review of literature consists of the gathering, critical evaluation and synthesis of results of multiple studies on a particular research topic (Costa \& Zoltowski, 2014). The steps of the review process were: (a) formulation and delimitation of the research question, (b) selection of data sources, (c) election of keywords for the search, (d) search for and organization of results, (e) selection of items according to the inclusion and exclusion criteria, (f) extraction of data from the selected articles, (g) evaluation of the articles, (h) synthesis and interpretation of the data.

\section{Search Strategies}

A search was conducted in five scientific electronic databases: Scopus, PubMed, Web of Science, PsycINFO and Biblioteca Virtual em Saúde - Psicologia (BVS-Psi). The keywords used in the search were selected from the list of psychological terms indexed in the ThesaurusAPA (American Psychological Association), these being: body image, morbid obesity, obesity and surgery. An initial attempt to specify the surgical weight reduction procedure as bariatric surgery resulted in the exclusion of potential articles for inclusion in the analysis. The surgical weight reduction procedures may receive different denominations, such as adjustable gastric banding surgery, sleeve gastrectomy surgery and gastric bypass surgery. Therefore, with the term surgery, different nomenclatures for weight reduction surgery were included. All terms were searched in search strings with the Boolean operator AND, as in the following description: (a) body image AND morbid obesity; (b) body image AND obesity; (c) body image AND morbid obesity AND surgery, (d) body image AND obesity AND surgery. The keywords and strings were repeated in Portuguese. Two researchers applied the inclusion and exclusion procedures independently. In cases of doubt, a third judge reviewed the abstracts to decide.

\section{Inclusion and Exclusion Criteria}

The inclusion criteria for analysis were:

1. To have been published between January 2009 and December 2014,

2. Articles published in English or Portuguese,

3. Articles with empirical results,

4. Articles reporting the specific use of at least one body image instrument, and

5. To have obese adult patients in the context of weight reduction surgery as the sample. Theoretical review articles, systematic literature reviews, meta-analyzes, theses and dissertations were excluded from the selection. The first record of articles repeated in more than one database was considered for analysis and the repetitions were ignored. The exclusion criterion was initially applied by reading the title and abstract of each article returned in the search. In a situation of doubt about the nature of the article, whether empirical or theoretical, the judges accessed the full texts for reapplication of the exclusion criteria. After this filter, the inclusion criteria were applied from the analysis of the article in full.

\section{Analysis Procedures}

The selected articles were read in full and analyzed according to the following descriptive categories: (a) weight characteristics and age of the sample of obese people studied, (b) characteristics of the body image evaluation instruments, (c) moments of body image evaluation related to the surgical intervention, (d) psychiatric comorbidities evaluated in the study samples, and (e) results of the measurement of body image in the studies.

\section{Results}

The search in the databases identified 462 articles. The first filtering of the abstracts resulted in the exclusion of 339 articles, which mostly represented articles repeated among the databas- 
es. After this filtering, 123 original articles were analyzed in their entirety for the application of the inclusion criteria, which resulted in the selection of 15 empirical articles (Figure 1).

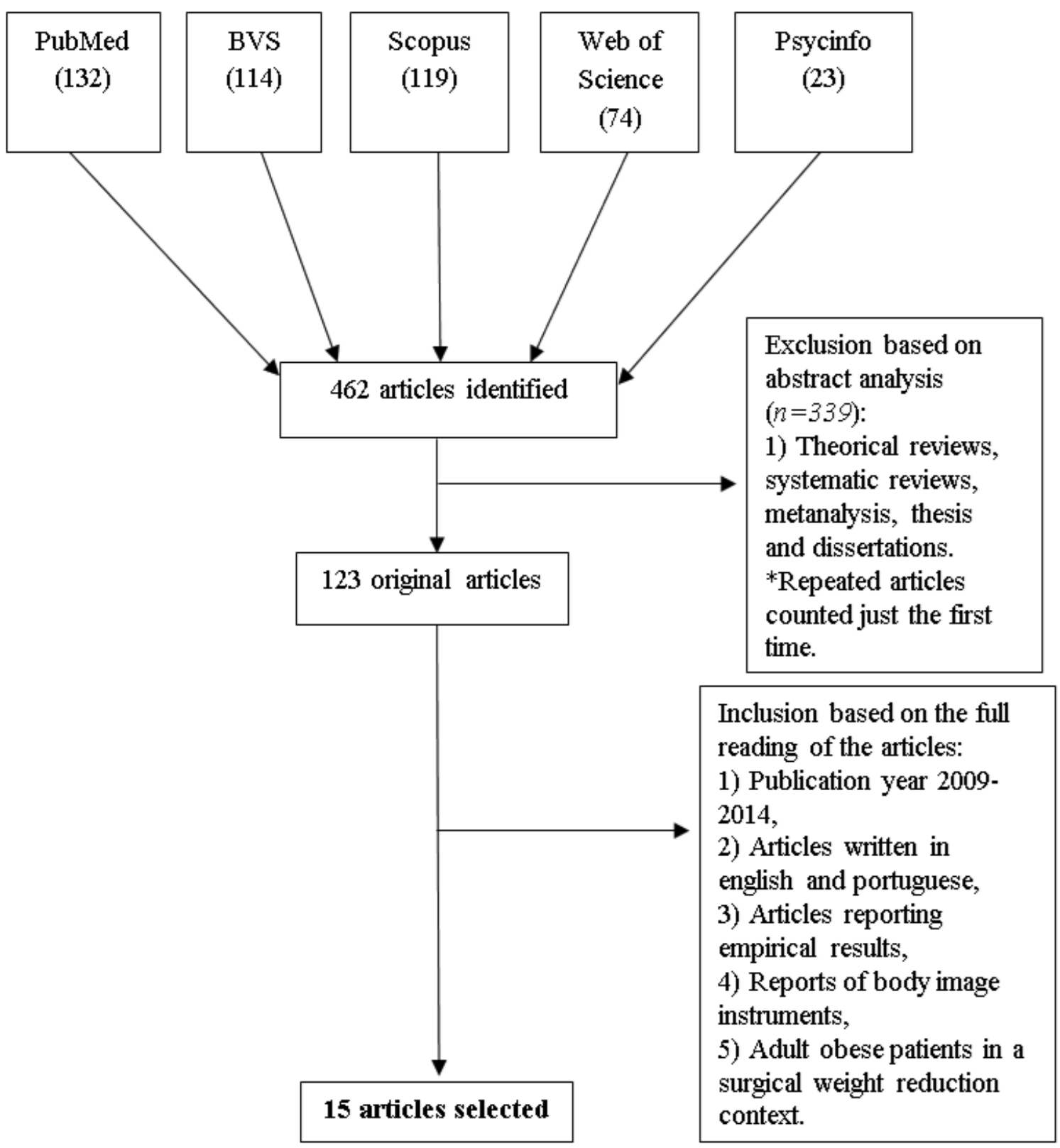

Figure 1. Flowchart of the selection, exclusion and inclusion of articles for analysis in the review.

The distribution of gender between the participants of the selected articles was homogeneous, with only one of them having its sample composed exclusively by women. The mean age of the participants of the articles of the review was 41.76 years. Four studies did not specify the mean age. The studies that measured the BMI of the participants in the pre-operative period $(n=12)$ showed a mean above $40 \mathrm{~kg} / \mathrm{m}^{2}$, typifying a pattern of grade III or morbid obesity.
In the set of selected articles, the use of nine different instruments to measure body image was identified. Each study used only one measure to evaluate body image, except for the study by Koller, Schubhart and Hintringer (2013) that made use of two. The scales used in over $50 \%$ of these articles were the Body Shape Questionnaire - BSQ $(n=5)$, developed by Cooper, Taylor, Cooper and Fairburn (1987), and the Figure Rating Scale $(n=3)$, initially created by Stunkard, 
Sorenson and Schulsinger (1983). Both instruments measure different aspects of body image. The BSQ measures the satisfaction and concern about the body and the body shape through 34 self-report items organized in a Likert scale of six points (Sousa et al., 2014). The Figure Rating Scale has different versions, however, the central idea of the instrument is to evaluate the satisfaction and body perception of individuals. This evaluation is carried out from the selection of a silhouette from a set of silhouette figures. The participant indicates the figure that best represents their body size now and the one closest to their ideal body size (Kakeshita, Silva, Zanata, \& Almeida, 2009).

Table 1

Articles Included in the Review

\begin{tabular}{|c|c|c|c|c|c|}
\hline Study & Sample & $\begin{array}{c}\text { BI } \\
\text { Instruments }\end{array}$ & $\begin{array}{l}\text { BI Evaluation } \\
\text { Moment }\end{array}$ & $\begin{array}{l}\text { Comorbi- } \\
\text { dities }\end{array}$ & BI results \\
\hline $\begin{array}{l}\text { Almeida, } \\
\text { Zanatta, \& } \\
\text { Rezende, } \\
2012\end{array}$ & $\begin{array}{l}17 \text { adults }(36.8 \pm \\
10.9 \text { years }) / \mathrm{BMI} \\
\text { pre-operative } \\
\text { period } 52.3 \pm 1.5 \\
\mathrm{~kg} / \mathrm{m}^{2}\end{array}$ & $\begin{array}{l}\text { Figure } \\
\text { Rating } \\
\text { Scale }\end{array}$ & $\begin{array}{l}\text { Pre-op / post-op } \\
6 \text { months / } \\
\text { Post-op } 12 \\
\text { months }\end{array}$ & $\begin{array}{l}\text { Mild } \\
\text { Depression }\end{array}$ & $\begin{array}{l}\text { Significant differences when } \\
\text { comparing the pre-op with the } \\
\text { post-op } 6 \text { months, } t(10)=6.59 \text {, } \\
p<.01 \text { and } 12 \text { months, } t(10)= \\
10.23, p<.01 \text {. No differences } \\
\text { between post-op } 6 \text { and } 12 \text { months. }\end{array}$ \\
\hline $\begin{array}{l}\text { Buser, } \\
\text { Lam, \& } \\
\text { Poplawski, } \\
2009\end{array}$ & 106 women & $\begin{array}{c}\text { Body } \\
\text { Image } \\
\text { State Scale }\end{array}$ & $\begin{array}{l}\text { Pre-op 6-18 } \\
\text { months / Post-op } \\
19-40 \text { months }\end{array}$ & Depression & $\begin{array}{l}\text { No significant differences in } \\
\text { body image between the groups } \\
\text { (1) sexual abuse and (2) no } \\
\text { abuse reported for the period of } \\
6 \text { - } 18 \text { months, } t(27)=4.67, p=.01 \text {. }\end{array}$ \\
\hline
\end{tabular}

176 adults (41.65

years) / Mean

BMI in pre-op

$44.19 \mathrm{~kg} / \mathrm{m}^{2}+$

110 adult (42.11

Conceição years)/ Mean

et al., 2013 BMI in the post-

op $44.46 \mathrm{~kg} / \mathrm{m}^{2}+$

$53($ age $=43,52)$

/ Mean BMI in

the post-op 45.13

$\mathrm{kg} / \mathrm{m}^{2}$

Grilo, $\quad 17$ adults (42.9

Henderson, years) / Mean

Bell, \& BMI pre-opera-

Crosby, tive period 50.2

$2013 \mathrm{~kg} / \mathrm{m}^{2}$

Kinzl,

Lanthaler,

180 adults (49

Stuerz, \& years) / BMI

Algner, pre-operative

2011

period $45 \mathrm{~kg} / \mathrm{m}^{2}$

252 adults $(46.1$

\pm 12.4 years $) /$

Kitzinger et

Mean BMI pre-

al., 2012

operative period

$47.5 \mathrm{~kg} / \mathrm{m}^{2}$ post-

operative 30.5

$\mathrm{kg} / \mathrm{m}^{2}$
Pre-op / Post-op

1 month - $24 \quad$ Eating

months / Disorders

Post-op 24 and

Questionnaire months Depression

onwards

Body

Shape Pre-operative Depression

Questionnaire

Body Shape 9-12 years

Questionnaire Post-operative

NA

Post-Bariatric

Satisfaction

At least 1 year

Questionnaire
Significant differences between patients with loss of control over food and no loss of control, with the first showing higher impaired body image scores and symptoms of eating disorders, $F(1,330)=7.79, p<.01$, both in the pre-operative and long-term post-operative period.

NA (study of factor structure and construct validity).

Positive correlation between high weight loss post-op and lower body rejection of their own bodies and better vital body dynamics $(p=.0001)$.

After weight loss caused by the surgery, both genders were dissatisfied with areas of the body such as the abdomen / waist, chest and thighs. 


\begin{tabular}{|c|c|c|c|c|c|}
\hline Study & Sample & $\begin{array}{l}\text { BI } \\
\text { Instruments }\end{array}$ & $\begin{array}{l}\text { BI Evaluation } \\
\text { Moment }\end{array}$ & $\begin{array}{l}\text { Comorbi- } \\
\text { dities }\end{array}$ & BI results \\
\hline $\begin{array}{l}\text { Koller et } \\
\text { al., } 2013\end{array}$ & $\begin{array}{l}27 \text { adults }(39.9 \\
\text { years }) / \text { Mean } \\
\text { BMI pre-opera- } \\
\text { tive period } 46.7 \\
\mathrm{~kg} / \mathrm{m}^{2} \text { Mean post- } \\
\text { operative weight } \\
71 \mathrm{~kg}\end{array}$ & $\begin{array}{l}\text { Body } \\
\text { Appraisal } \\
\text { Inventory }\end{array}$ & $\begin{array}{l}2 \text { weeks Pre-op / } \\
6 \text { months } \\
\text { Post-op }\end{array}$ & NA & $\begin{array}{l}\text { Weight loss after surgery } \\
\text { improved the quality of life and } \\
\text { body image }(p<.05)\end{array}$ \\
\hline $\begin{array}{l}\text { Munoz et } \\
\text { al., } 2010\end{array}$ & $\begin{array}{l}57 \text { adults }(39 \pm \\
4.3 \text { years }) / \text { Mean } \\
\text { pre-op BMI } 52.54 \\
\mathrm{~kg} / \mathrm{m}^{2}\end{array}$ & $\begin{array}{l}\text { Figure Rating } \\
\text { Scale }\end{array}$ & $\begin{array}{l}\text { Pre-op / } 1 \text { year } \\
\text { Post-op }\end{array}$ & NA & $\begin{array}{l}\text { significant decrease in the } \\
\text { difference between the ideal } \\
\text { body shape and the current body } \\
\text { shape }(t=2.63, p=.02) \text { after } \\
\text { surgery. }\end{array}$ \\
\hline $\begin{array}{l}\text { Ortega et } \\
\text { al., } 2012\end{array}$ & $\begin{array}{l}60 \text { adults / Mean } \\
\text { pre-op BMI } 44.9 \\
\pm 6.3 \mathrm{~kg} / \mathrm{m}^{2} / \\
\text { Mean BMI in the } \\
6 \text { month post-op } \\
34.1 \pm 4.7 \mathrm{~kg} / \mathrm{m}^{2} \\
/ \text { Mean BMI in } \\
\text { the } 1 \text { year post-op } \\
29.9 \pm 4.8 \mathrm{~kg} / \mathrm{m}^{2}\end{array}$ & $\begin{array}{l}\text { Body Shape } \\
\text { Questionnaire }\end{array}$ & $\begin{array}{l}\text { Pre-op / } 6 \\
\text { months post-op / } \\
1 \text { months } \\
\text { post-op }\end{array}$ & $\begin{array}{l}\text { Depression, } \\
\text { Anxiety and } \\
\text { Obsessive- } \\
\text { Compulsive } \\
\text { Disorder. }\end{array}$ & $\begin{array}{l}\text { Negative body image correlated } \\
\text { with obsessive-compulsive } \\
\text { disorder, depression, anxiety, } \\
\text { general anxiety index }(p<.001) \text {, } \\
\text { paranoid ideation }(p<.05) \text { and } \\
\text { psychoticism }(p<.01) \text { one year } \\
\text { after surgery. }\end{array}$ \\
\hline $\begin{array}{l}\text { Ribeiro et } \\
\text { al., } 2013\end{array}$ & 423 adults & $\begin{array}{l}\text { Figure Rating } \\
\text { Scale }\end{array}$ & $\begin{array}{l}\text { Pre-operative / } \\
\text { Post-operative } \\
\text { - five groups: 1) } \\
\text { pre-operative, } \\
\text { 2) } 12 \text { months } \\
\text { post-operative, } \\
\text { 3) 12-24 months } \\
\text { post-operative, } \\
\text { 4) } 25-36 \text { months } \\
\text { post-operative, } \\
\text { 5) }+37 \text { months. }\end{array}$ & NA & $\begin{array}{l}\text { Significant differences in pre- } \\
\text { op in relation to all groups in } \\
\text { the choice of larger figures } \\
\text { representing the actual size } \\
(p<.001) \text {. The Pre-O group } \\
\text { differed from the PO-1, } \\
\text { PO- } 2 \text { and PO-3 groups, with } \\
\text { a tendency to choose larger } \\
\text { silhouettes after the surgery ( } \\
<.001) \text {. In relation to the size } \\
\text { they would like to have been, } \\
\text { the PO- } 4 \text { group differed from } \\
\text { PO- } 1 \text { and PO- } 2 \text { ( } p<.05) \text {, with } \\
\text { a tendency to choose larger } \\
\text { figures. }\end{array}$ \\
\hline $\begin{array}{l}\text { Sarwer et } \\
\text { al., } 2013\end{array}$ & $\begin{array}{l}250 \text { adults / Mean } \\
\text { BMI } 44.6 \mathrm{~kg} / \mathrm{m}^{2} .\end{array}$ & $\begin{array}{l}\text { Body Shape } \\
\text { Questionnaire }\end{array}$ & $\mathrm{NI}^{*}$ & $\begin{array}{l}\text { Sexual } \\
\text { Dysfunction } \\
\text { and } \\
\text { Depression }\end{array}$ & $\begin{array}{l}\text { There were no significant } \\
\text { differences. }\end{array}$ \\
\hline $\begin{array}{l}\text { Sousa et al., } \\
2014\end{array}$ & $\begin{array}{l}52 \text { adults }(44.04 \\
\text { years), NI* }\end{array}$ & & $\begin{array}{l}\text { Post-operative } \\
\text { (more than } 2 \\
\text { years) }\end{array}$ & $\begin{array}{l}\text { Depression, } \\
\text { Acute } \\
\text { compulsive } \\
\text { food intake } \\
\text { and Bulimia } \\
\text { Nervosa }\end{array}$ & $\begin{array}{l}\text { The compulsive food intake, the } \\
\text { BMI \% gain after surgery and } \\
\text { the concern with body image } \\
\text { explained } 50 \% \text { of the variance } \\
\text { of depression after surgery } \\
(R 2=0.46) \text { being significant } \\
F(3.43)=14.117, \quad p<.001 . \\
\text { Greater dissatisfaction with } \\
\text { body image was associated with } \\
\text { more depressive symptoms, } \beta= \\
0.535, t=3.71, p=.001 .\end{array}$ \\
\hline
\end{tabular}




\begin{tabular}{|c|c|c|c|c|c|}
\hline Study & Sample & $\begin{array}{c}\text { BI } \\
\text { Instruments }\end{array}$ & $\begin{array}{l}\text { BI Evaluation } \\
\text { Moment }\end{array}$ & $\begin{array}{l}\text { Comorbi- } \\
\text { dities }\end{array}$ & BI results \\
\hline $\begin{array}{l}\text { van Hout } \\
\text { et al., } 2009\end{array}$ & $\begin{array}{l}112 \text { adults }(38.08 \\
\pm 8.3 \text { years }) / \\
\text { Mean pre-op BMI } \\
45.3 \pm 5.1 \mathrm{~kg} / \mathrm{m} 2\end{array}$ & $\begin{array}{l}\text { Body } \\
\text { Attitude } \\
\text { Test }\end{array}$ & $\begin{array}{l}\text { Pre-op / post-op } \\
\text { ( } 2 \text { years after } \\
\text { surgery) }\end{array}$ & $\begin{array}{l}\text { Eating } \\
\text { Disorders, } \\
\text { Social } \\
\text { Anxiety and } \\
\text { Neuroses }\end{array}$ & $\begin{array}{l}\text { The body image explained more } \\
\text { than } 25 \% \text { of the variance in the } \\
\text { change in body attitude two } \\
\text { years post-op }(p<.001)\end{array}$ \\
\hline $\begin{array}{l}\text { Wimmel- } \\
\text { mann et al., } \\
2014\end{array}$ & $\begin{array}{l}129 \text { adults }(39.6 \pm \\
9.5 \text { years }) / \text { pre-op } \\
\text { BMI } 42.91 \pm 5.77 \\
\mathrm{~kg} / \mathrm{m}^{2}\end{array}$ & $\begin{array}{l}\text { Body } \\
\text { Shape } \\
\text { Questionnaire }\end{array}$ & $\begin{array}{l}\text { Approximately } \\
12 \text { months } \\
\text { Pre-op }\end{array}$ & $\begin{array}{l}\text { Personality } \\
\text { and Type } 2 \\
\text { Diabetes }\end{array}$ & $\begin{array}{l}\text { Patients with type } 2 \text { diabetes } \\
\text { had better body image than } \\
\text { the patients without diabetes } \\
(p<.05)\end{array}$ \\
\hline $\begin{array}{l}\text { Zwaan et } \\
\text { al., } 2014\end{array}$ & $\begin{array}{l}393 \text { adults }(41.63 \\
\text { years }) / \text { pre-op } \\
\text { BMI } 48.74 \mathrm{~kg} / \mathrm{m}^{2}\end{array}$ & $\begin{array}{l}\text { Multidimen- } \\
\text { sional } \\
\text { Body-Self } \\
\text { Relations } \\
\text { Questionnaire }\end{array}$ & $\begin{array}{l}\text { Pre and Post-op } \\
\text { (at least } 1 \text { year } \\
\text { after surgery) }\end{array}$ & $\begin{array}{l}\text { Depression } \\
\text { and Anxiety }\end{array}$ & $\begin{array}{l}\text { Patients reported better evalu- } \\
\text { ation of appearance, body area } \\
\text { satisfaction and physical func- } \\
\text { tioning after body contouring } \\
\text { surgery }(p<.001)\end{array}$ \\
\hline
\end{tabular}

Note. NI*: No information. NA: Not evaluated.

Other instruments were used in the articles selected. The Body Image Questionnaire (Clement \& Löwe, 1996), which investigates the external appearance and sense of well-being with one's own body and the energetic and movement components of the body image. The Body Image State Scale (Cash \& Pruzinsky, 2002), which evaluates the momentary affective experiences in relation to the physical appearance of the individual. The Body Image Inventory (Koller et al., 2013), which evaluates negative subjective aspects in relation to the body, as well as evaluates the perception of body dynamics and vitality. The Body Appraisal Inventory (Strauß \& Appelt, 1983), which seeks to examine insecurity, discomfort, attractiveness, self-confidence, accentuation and sensitivity in relation to the body of the participants. The Body Attitude Test (Probst, Vandereycken, van Coppenolle, \& Vanderlinden, 1995), which was developed to measure the subjective experience and attitude towards one's own the body. Finally, the Multidimensional Body-Self Relations Questionnaire (Cash, 1991), which investigates dimensions of the relationship with one's own body image, such as the importance of the perceived appearance and its influence on the individual's behavior.
Kitzinger et al. (2012) developed a scale for their study, the Post-Bariatric Satisfaction Questionnaire, with its main focus being on aesthetic concerns and body shape after weight reduction surgery. Of the nine body image evaluation instruments identified in the review, the Figure Rating Scale is the only one that evaluates the perceptual dimension of the body image. The other eight instruments measure the subject's attitude and the level of satisfaction with his/her own body.

The articles selected showed different strategies in relation to the moment of evaluation of the body image. In approximately half of the studies the evaluation took place in two stages, before and after the surgery $(n=8)$. The other articles were divided between only presurgical evaluations $(n=3)$ or only post-surgical evaluations $(n=4)$. There was no standardization regarding the precise moment that the body image was evaluated in the pre-surgery period. In the articles that specify this information, this varied from two weeks to 12 months prior to the surgery, indicating amplitude of evaluation time and low homogeneity regarding measurement criteria. Among the articles that performed the post-surgical evaluation, all defined the time of evaluation, however, with a large variation in 
time, from one month to 12 years, as observed in the pre-surgical evaluation.

Among the 15 selected articles, 10 investigated comorbidities associated with the obesity. The majority $(n=8)$ assessed symptoms of depression, followed by eating disorders $(n=3)$ and anxiety $(n=3)$. Only two of the 10 studies that investigated comorbidities found associations between psychiatric disorders and body image. Sousa et al. (2014) showed that concern about body image coupled with compulsive food intake and the percentage of BMI gained after surgery explained $50 \%$ of the variance of postsurgery depression. The study by Ortega et al. (2012) found that negative body image in the pre-surgical period correlated with psychiatric symptoms of obsessive-compulsive disorder, depression, anxiety, general index of anxiety, paranoid ideation and psychoticism one year after the surgery.

All the studies that evaluated the body image before and after surgery $(n=9)$ presented significant differences in the variable in the postoperative period. In general, the differences in the post-surgical period were related to greater satisfaction with the body image, to decreased perception of difference between the current and ideal body shape, to the choice of smaller silhouettes representing the size itself and to better evaluation of the appearance, satisfaction with areas of the body and physical functioning.

\section{Discussion}

The review identified that although evaluation of body image occur in patients that are candidates for weight reduction surgery, there is a prevalence of focus on evaluating the attitudinal dimension of the construct. The attitudinal dimension was observed in the description of the articles as a measure of satisfaction in relation to the patient's own body. Evaluations of the perceptual dimension of body image, characterized in the studies as perception of the size of silhouettes or body figures, were less frequent. Tavares, Campana e Campana (2010) corroborate the finding that there are few studies in the literature that effectively investigate the perceptual dimension of the body image. Conversely, in studies with patients diagnosed with Bulimia Nervosa and Anorexia Nervosa the use of perceptual measures of body image seems to be more frequent (Saikali, Soubhia, Scalfaro, \& Cordás, 2004).

This difference in use probably refers to the differential diagnostic value from measuring perceptual aspects in obese populations and individuals with eating disorders. It is unclear in the literature on obesity whether perceptual functions are compromised by the accumulation of weight. However, a rapid change in body size, as seen in the results of weight loss surgery, could result in major perceptive and proprioceptive changes. This hypothesis would justify the increase of the pre- and post-surgical investigation of both the perceptive dimension and the attitudinal dimension of the body image. The value of the variable in an evaluation protocol can be exemplified by the study by Simonsen, Hundrup, Obel, Gronbaek and Heitmann (2008). The researchers showed that obese individuals with distorted body image will have more impairments to their health than those with high BMI alone. In other words, obese individuals with the same weight will have different health outcomes depending on how they perceive their own bodies.

Regarding pre and post surgery evaluation, the heterogeneity in the moments of body image evaluation in the context of weight reduction surgery was highlighted in the review. Although more than half of the studies performed the evaluation before and after the surgery, the specific timing of this evaluation was not homogeneous, varying in both the pre- and postoperative periods. In the construction of psychological evaluation protocols, the windows of measurement of variables are a crucial factor for comparability between studies and for the development of more objective and precise protocols (American Educational Research Association [AERA], APA, \& National Council on Measurement in Education [NCME], 2014). This comparison helps to ensure the validity of the evaluations, with this being an extremely important factor in the development and appli- 
cation of psychological tests, especially when used for diagnostic purposes. One hypothesis that could explain this variability in the moments of body image evaluation, as noted in the review, is the more exploratory trend of the selected articles regarding the association between body image and clinical outcomes.

Although exploratory, the weight reduction interventions were shown to be correlated to changes in the body image of individuals. In general, the studies showed improvements in both the attitudinal dimension and the perceptual dimension after the surgery. Only one article identified dissatisfaction with some areas of the body in the post-operative period (Kitzinger et al., 2012). In addition, a negative body image was identified as a significant variable associated with depression, anxiety and eating disorders. The way body image has an important role in the prognosis of surgical interventions can be perceived (Koller et al., 2013), although in the revision one third of the articles did not evaluate comorbidities of the obesity. A larger number of articles was expected considering that body image is a variable of primarily psychological research (Saur, 2007) and the studies selected for analysis had a mental health evaluation character.

This review found similar results to the study of Pull and Aguayo (2011) regarding the heterogeneity of definitions for the operationalization of the body image in research. This is mainly reflected in the high number of instruments dedicated to the evaluation of the body image. This finding shows that there has not been many advances in the literature regarding the conceptualization and measurement of body image in the past four years. Accordingly, the task of comparison of the results of studies that evaluate body image remains difficult.

Despite the emphasis given in the literature to the impact that changes in body image cause in morbidly obese people, the present review showed that the evaluation of the variable is not uniform. However, there is a trend of evaluation of the level of the patients' subjective satisfaction with their own bodies, although using different instruments. Few studies have evaluated the psychophysical aspects of the perception of body image. One of the limitations of the review was that it only evaluated articles published in the Portuguese and English languages, not including research on the subject in other languages. The low homogeneity of operational definitions for body image could constitute a further limitation of the review, which was related to defining the search criteria including only articles with the term body image. Future analyzes should explore the difference between body image evaluation protocols among obese people and other clinical populations in which this variable has a more clearly defined prognostic role.

\section{References}

American Educational Research Association, American Psychological Association, \& National Council on Measurement in Education. (2014). Standards for Educational and Psychological Testing. Washington, DC: American Educational Research Association Publications Sales.

Almeida, S. S., Zanatta, D. P., \& Rezende, F. F. (2012). Imagem corporal, ansiedade e depressão em pacientes obesos submetidos à cirurgia bariátrica. Estudos de Psicologia (Natal), 17(1), 153-160. doi:10.1590/S1413-294X2012000100019

Altabe, M. N., \& Thompson, J. K. (1996). Body image: A cognitive self-schema construct? Cognitive Therapy and Research, 20(2), 171193. doi:10.1007/BF02228033

Bruce, D. M., \& Mitchell, A. I. (2014). Surgery for obesity. Medicine, 43(2), 101-103. doi:10.1016/j. mpmed.2014.11.001

Buchwald, H., Avidor, Y., Braunwald, E., Jensen, M. D., Pories, W., Fahrbach, K., \& Schoelles, K. (2004). Bariatric surgery: A systematic review and meta-analysis. The Journal of the American Medical Association, 292(14), 1724-1737. doi:10.15406/aowmc.2015.02.00011

Buser, A. T., Lam, C. S., \& Poplawski, C. S. (2009). A long-term cross-sectional study on gastric bypass surgery: Impact of self-reported past sexual abuse. Obesity Surgery, 19(4). doi:10.1007/s11695-008-9555-2

Carr, D., \& Jaffe, K. (2012). The psychosocial consequences of weight change trajectories: Evidence from quantitative and qualitative data. 
Economics and Human Biology, 10(4), 419-430. doi:10.1016/j.ehb.2012.04.007

Cash, T. F. (1991). Binge-eating and body images among the obese: A further evaluation. Journal of Social Behavior and Personality, 6, 367-376.

Cash, T. F., \& Pruzinsky, T. (2002). Body image: A handbook of theory, research, and clinical practice. New York: Guilford Press. doi:10.1056/ NEJM200304033481428

Clement, U., \& Löwe, B. (1996). Validation of the FKB-20 as scale for the detection of body image distortions in psychosomatic patients. Psychotherapie, Psychosomatik, Medizinische Psychologie, 46(7), 254-259.

Conceição, E., Bastos, A. P., Brandão, I., Vaz, A. R., Ramalho, S., Arrojado, F., ...Machado, P. P. (2013). Loss of control eating and weight outcomes after bariatric surgery: A study with a Portuguese sample. Eating and Weight Disorders, 19(1), 103-109. doi:10.1007/s40519-0130069-0

Conde, W. L., \& Borges, C. (2011). O risco de incidência e persistência da obesidade entre adultos brasileiros segundo seu estado nutricional ao final da adolescência. Revista Brasileira de Epidemiologia, 14(1), 71-79. doi:10.1590/S1415-790X2011000500008

Cooper, P. J., Taylor, M. J., Cooper, Z., \& Fairburn, C. J. (1987). The development and validation of the Body-Shape Questionnaire. International Journal of Eating Disorders, 6(4), 485-494.

Costa, A. B., \& Zoltowski, A. P. C. (2014). Como escrever um artigo de revisão sistemática. In S. H. Koller, M. C. P. de Paula Couto, \& J. V. Hohendorff (Eds.), Manual de Produção Cientifica (pp. 55-70). Porto Alegre, RS: Penso.

Dhurandhar, E. J., \& Keith, S. W. (2014). The aetiology of obesity beyond eating more and exercising less. Best Practice \& Research Clinical Gastroenterology, 28(4), 533-544. doi:10.1016/j.bpg.2014.07.001

Fabricatore, A. N., Crerand, C. E., Wadden, T. A., Sarwer, D. B., \& Krasucki, J. L. (2006). How do mental health professionals evaluate candidates for bariatric surgery? Survey results. Obesity Surgery, 16(5), 567-573.

Finer, N. (2011). Medical consequences of obesity. Medicine Journal, 39(1), 18-23. doi:10.1016/j. mpmed.2010.11.008
Friedman, M. A., \& Brownell, K. D. (1995) Psychological correlates of obesity: Moving to the next research generation. Psychological Bulletin, 117(1), 3-20. doi:10.1037//0033-2909.117.1.3

Gianos, M., Abdemur, A., Fendrich, I., Gari, V., Szomstein, S., \& Rosenthal, R. J. (2012). Outcomes of bariatric surgery in patients with body mass index $<35 \mathrm{~kg} / \mathrm{m} 2$. Surgery for Obesity and Related Diseases, 8(1), 25-30. doi:10.1016/j. soard.2011.08.012

Grilo, C. M., Henderson, K. E., Bell, R. L. \& Crosby, R. D. (2013). Eating disorder examination-questionnaire factor structure and construct validity in bariatric surgery candidates. Obesity Surgery, 23(5). doi:10.1007/s11695-012-0840-8

Guh, D. P., Zhang, W., Bansback, N., Amarsi, Z., Birmingham, C. L., \& Anis, A. H. (2009). The incidence of co-morbidities related to obesity and overweight: A systematic review and meta-analysis. BMC Public Health, 88(9), 1-20. doi:10.1186/1471-2458-9-88

Holsen, I., Carlson, D. J., \& Skogbrott, M. B. (2012). Body image satisfaction among Norwegian adolescents and young adults: A longitudinal study of the influence of interpersonal relationships and BMI. Body Image, 9(2). doi:10.1056/ NEJM200304033481428

Hu, F. B. (2008). Obesity epidemiology. New York: Oxford University Press.

Kakeshita, I. S., Silva, A. I. P., Zanatta, D. P., \& Almeida, S. S. (2009). Construção e fidedignidade teste-reteste de escalas de silhuetas brasileiras para adultos e crianças. Psicologia: Teoria $e$ Pesquisa, 25, 263-270.

Kinzl, J. F., Schrattenecker, M., Traweger, C., Mattesich, M., Fiala, M., \& Biebl, W. (2006). Psychosocial predictors of weight loss after bariatric surgery. Obesity Surgery, 16(12), 1609-1614. doi:10.1381/096089206779319301

Kinzl, J. F., Lanthaler, M., Stuerz, K., \& Aigner, F. (2011). Long-term outcome after laparoscopic adjustable gastric banding for morbid obesity. Eating Weight Disorders, 16(4), 250-256. doi: $10.3275 / 7752$

Kitzinger, H. B., Abayev, S., Pittermann, A., Karle, B., Kubiena, H., Bohdjalian, A., ...Frey, M. (2012). The prevalence of body contouring surgery after gastric bypass surgery. Obesity Surgery, 22(1), 8-12. doi:10.1007/s11695-0110459-1 
Koller, M., Schubhart, S., \& Hintringer, T. (2013). Quality of life and body image after circumferential body lifting of the lower trunk: A prospective clinical trial. Obesity Surgery, 23(4), 561-566. doi:10.1007/s11695-012-0849-z

Liechty, J. M., \& Lee, M. J. (2015). Body size estimation and other psychosocial risk factors for obesity onset among US adolescents: Findings from a longitudinal population level study. International Journal of Obesity, 39. doi:10.1038/ ijo.2014.191

Maggard, M. A., Shugarman, L. R., Suttorp, M., Maglione, M., Sugerman, H. J., Livingston, E. H., ...Shekelle, P. G. (2005). Meta-analysis: Surgical treatment of obesity. Annals of Internal Medicine, 142(7), 547-584. doi:10.7326/00034819-142-7-200504050-00013

Munoz, D., Chen, E. Y., Fischer, S., Sanchez-Johnsen, L., Roherig, M., Dymek-Valentine, M., ... Le Grange, D. (2010). Changes in desired body shape after bariatric surgery. Eating Disorders, 18(4), 347-54. doi:10.1080/10640266.2010.490 126

Ortega, J., Fernandez-Canet, R., Alvarez-Valdeita, S., Cassinello, N., \& Baguena-Puigcerver, M. J. (2012). Predictors of psychological symptoms in morbidly obese patients after gastric bypass surgery. Surgery for Obesity and Related Diseases, 8(6), 770-776. doi:10.1016/j. soard.2011.03.015

Picot, J., Jones, J., Colquitt, J. L., Gospodarevskaya, E., Loveman, E., Baxter, L., \& Clegg, A. J. (2009). The clinical effectiveness and costeffectiveness of bariatric (weight loss) surgery for obesity: A systematic review and economic evaluation. Health Technology Assessment, 13(41). doi:10.3310/hta13410

Popkin, B. M. (2007). Global context of obesity. In S. Kumanyika \& R. Brownson, Handbook of Obesity Prevention (pp. 227-238). New York: Springer.

Probst, M., Vandereycken, W., van Coppenolle, H., \& Vanderlinden, J. (1995). The body attitude test for patients with an eating disorder: Psychometric characteristics of a new questionnaire. Eating Disorders, 3(2), 133-144.

Pull, C. B. (2010). Current psychological assessment practices in obesity surgery programs: What to assess and why. Current Opinion in Psychiatry, 23(1), 30-36. doi:10.1097/ YCO.0b013e328334c817
Pull, C. B., \& Aguayo, G. A. (2011). Assessment of body-image perception and attitudes in obesity. Current Opinion in Psychiatry, 24(1). doi:10.1097/YCO.0b013e328341418c

Ribeiro, G. A. N. A., Giampietro, H. B., Barbieri, L. B., Pacheco, R. G., Queiroz, R., \& Ceneviva, R. (2013). Percepção corporal e cirurgia bariátrica: $\mathrm{O}$ ideal e o possível. Arquivos Brasileiros de Cirurgia Digestiva, 26(2), 124-128.

Saikali, C. J., Soubhia, C. L., Scalfaro, B. M., \& Cordás, T. A. (2004). Imagem corporal nos transtornos alimentares. Revista de Psiquiatria Clínica, 31(4), 164-166.

Salihu, H. M., Bonnema, S. M., \& Alio, A. P. (2009). Obesity: What is an elderly population growing into? Maturitas, 63(1), 7-12. doi:10.1016/j.maturitas.2009.02.010

Sarwer, D. B., Spitzer, J. C., Wadden, T. A., Rosen, R. C., Mitchell, J. E., Lancaster, K., ...Christian, N. J. (2013). Sexual functioning and sex hormones in persons with extreme obesity and seeking surgical and nonsurgical weight loss. Surgery for Obesity and Related Diseases: Official Journal of the American Society for Bariatric Surgery, 9(6), 997-1007. doi:10.1016/j. soard.2013.07.003

Saur, A. M. (2007). Imagem corporal: Auto-satisfação e representação psíquica em Desenhos da Figura Humana (Masters thesis, Universidade de São Paulo, Ribeirão Preto, SP, Brazil).

Simonsen, M. K., Hundrup, Y. A., Obel, E. B., Gronbaek, M., \& Heitmann, B. L. (2008). Intentional weight loss and mortality among initially healthy men and women. Nutrition Reviews, 66(7), 375386. doi:10.1111/j.1753-4887.2008.00047.x

Skelton, J. A., Cook, S. R., Auinger, P., Klein, J. D., $\&$ Barlow, S. E. (2009). Prevalence and trends of severe obesity among US children and adolescents. Academic Pediatrics, 9(5), 322-329. doi:10.1016/j.acap.2009.04.005

Skelton, J. A., Irby, M. B., Grywacz, J. G., \& Miller, G. (2011). Etiologies of obesity in children: Nature and nurture. Pediatric Clinics of North America, 58(6), 1333-1354. doi:10.1016/j. pcl.2011.09.006

Sousa, P., Bastos, A. P., Venancio, C., Vaz, A. R., Brandão, I., Costa, J. M., ...Conceição, E. (2014). Compreender a sintomatologia depressiva após a cirurgia bariátrica: $\mathrm{O}$ papel do peso, da alimentação e da imagem corporal. Acta Médica Portuguesa, 27(4), 450-457. 
Strauß, B., \& Appelt, H. (1983). Ein Fragebogen zur Beurteilung des eigenen Körpers. Diagnostica, 29, 145-164.

Stunkard, A. J., Sorenson, T., \& Schlusinger, F. (1983). Use of the Danish adoption register for the study of obesity and thinness. In S. S. Kety, L. P. Rowland, R. L. Sidman, \& S. W. Mathysse (Eds.), The genetics of neurologic and psychiatric disorders (pp. 115-120). New York: Raven.

Tavares, M. C. G. C. F., Campana, A. N. N. B., Filho, R. F. T., \& Campana, M. B. (2010). Avaliação perceptiva da imagem corporal: História, reconceituação e perspectivas para o Brasil. Psicologia em Estudo, 15(3), 509-518.

Thompson, J. K. (2004). The (mis)measurement of body image: Ten strategies to improve assessment for applied and research purposes. Body Image, 1(1), 7-14. doi:10.1016/S17401445(03)00004-4

Van Hout, G. C., Hagendoren, C. A., Verschure, S. K., \& van Heck, G. L. (2009). Psychosocial predictors of success after vertical banded gastroplasty. Obesity Surgery, 19, 701-707. doi:10.1007/ s11695-008-9446-6
Zwaan, M., Georgiadou, E., Stroh, C. E., Teufel, M., Köhler, H., Tengler, M., \& Müller, A. (2014). Body image and quality of life in patients with and without body contouring surgery following bariatric surgery: A comparison of pre- and post-surgery groups. Frontiers in Psychology, 18(5), 1310. doi:10.3389/fpsyg.2014.01310

Wimmelmann, C. L., Dela, F., \& Mortensen, E. L. (2014). Psychological predictors of weight loss after bariatric surgery: A review of the recent research. Obesity Research \& Clinical Practice, 8(4), 299-313. doi:10.1016/j.orcp.2013.09.003

World Health Organization. (1997). Obesity. Preventing and managing the global epidemic (Report of a WHO Consultation on Obesity). Geneva, Switzerland: Author.

Recebido: 09/10/2015

$1^{a}$ revisão: 14/01/2016

Aceite final: 14/01/2016 